\title{
Het rechte pad
}

\section{Toekomstverwachtingen van langgestrafte gedetineerden in Nederland}

\author{
Jennifer Doekhie, Anja Dirkzwager \& Paul Nieuwbeerta
}

Maandagmiddag 13.00. In de spreekkamer van de penitentiaire inrichting wacht ik op Ab (24 jaar). Hij is een langer gestrafte gedetineerde en heeft de afgelopen tweeënhalf jaar in vier verschillende gevangenissen gezeten voor een gewapende overval. Over een paar dagen zit zijn straf erop en komt hij vrij. Ab is een vrolijke jongen die open begint te vertellen over zijn leven en ervaringen in detentie. Zo vertelt hij over het vuurwapen dat in zijn kluis werd gevonden op de middelbare school toen hij 15 was. Over het vele geld dat hij heeft verdiend, over de drugs waarin hij handelde. Hoe zijn oudere broer is doodgeschoten in de wereld van diezelfde drugs. Maar hij vertelt ook over zijn normen en waarden en de regel dat hij liever geen geweld gebruikt. Dat hij kinderen wil en trouwen met zijn vriendin die al die jaren bij hem is gebleven. Als ik hem vraag hoe hij zijn leven voor zich ziet als hij straks vrij is, valt hij even stil: 'Dit is het enige waar ik goed in ben, ik weet niet wat ik anders zou moeten doen.' Op de vraag waar hij zichzelf ziet over vijf jaar, komt er een nog diepere frons op zijn voorhoofd. Ik grap dat ik hem wel flink na laat denken op deze maandagmiddag, waarop hij peinzend antwoordt: 'Meer dan ik hier in al die jaren heb gedaan.'

\section{Inleiding}

Gewapende overvallen, verduistering, inbraken met geweld en poging tot doodslag vormen een greep uit de veelvoorkomende delicten waar de relatief kleine groep langer gestraften in Nederland voor wordt veroordeeld. Hoewel het een klein percentage van de totale groep gedetineerden betreft (2\%), verlaten in de jaren 2011-2015 elk jaar ongeveer 1000 personen een penitentiaire inrichting na een verblijfsduur van twee tot vier jaar. ${ }^{1}$ Dit artikel gaat in op deze laatste groep. Meer kennis over deze groep is belangrijk, omdat zij enerzijds verantwoordelijk is voor de meer ernstige criminaliteit en anderzijds omdat het een groep gedetineer-

1 P. Linckens, H. Valstar \& N. van Gemmert, DJI in getal 2011-2015, Den Haag: Dienst Justitiële Inrichtingen 2015. 
den is waar nog vrij weinig over bekend is. Wel is bekend dat de recidivecijfers voor langer gestrafte gedetineerden, net als bij andere groepen, hoog zijn. ${ }^{2}$

Tijdens en zeker tegen het einde van de detentie hebben gedetineerden tijd om na te denken over het leven buiten de muren straks, zoals hoe het zal zijn om familie en dierbaren weer te zien en op zoek te gaan naar een baan. ${ }^{3}$ Dit artikel exploreert het toekomstbeeld dat langer gestrafte gedetineerden in Nederland hebben ten aanzien van het al dan niet stoppen met criminaliteit en de factoren die hierbij een rol spelen. Het is van belang om meer te weten te komen over verwachtingen en percepties van de toekomst, omdat deze kunnen samenhangen met daadwerkelijk gedrag en dus met recidive. ${ }^{4}$ Verondersteld wordt dat criminologische theorieën waarbij sociale factoren, zoals werk, woning en wederhelft, ${ }^{5}$ en individuele factoren, zoals agency, ${ }^{6}$ gebruikt worden ter verklaring van hoe en waarom mensen stoppen met criminaliteit, tevens een rol kunnen spelen bij de verwachting om te stoppen met criminaliteit. De volgende onderzoeksvragen staan centraal:

1 Wat zijn de toekomstverwachtingen ten aanzien van crimineel gedrag van langgestrafte gedetineerden?

2 Hoe hangen sociale en individuele factoren samen met de toekomstverwachtingen ten aanzien van crimineel gedrag van langgestrafte gedetineerden?

Om de onderzoeksvragen te beantwoorden zijn semigestructureerde diepte-interviews afgenomen met 28 langer gestrafte gedetineerden die op het moment van uitstroom minimaal tweeënhalf jaar in detentie zaten. Aan hen zijn onder andere vragen gesteld over de verwachting om al dan niet te stoppen met criminaliteit en over factoren die hiermee kunnen samenhangen, zoals sociale steun, geloof in eigen kunnen en een gevoel van controle over je eigen leven.

2 Recidivecijfers van ex-gedetineerden na een detentieduur van één jaar of meer verschillen niet veel van personen die korter dan twee weken in detentie hebben doorgebracht. Voor beide groepen is de tweejarige strafrechtelijke (algemene) recidive in 2008 circa 46\%; G. Weijters, P.A. More \& S.M. Alma, Nazorgproblematiek en recidive van kortgestrafte gedetineerden, Den Haag: WODC 2010.

3 J. Irwin, The Felon, Englewood Cliffs, NJ: Prentice-Hall 1970; S.C. Richards \& R.S. Jones, 'Perpetual incarceration machine: Structural impediments to postprison success', Journal of Contemporary Criminal Justice 1997, 13, p. 4-22.

4 P.C. Giordano, R.D. Schroeder \& S.A. Cernkovich, 'Emotions and crime over the life course: A neo-Meadian perspective on criminal continuity and change', The American Journal of Sociology 2007, 112, p. 1603-1661; R. Burnett, The dynamics of recidivism, Oxford, VK: Centre for Criminological research, University of Oxford 1992; S. Maruna, Making good: how ex-convicts reform and rebuild their lives, Washington: American Pyschological Association 2001; R. Paternoster \& S. Bushway, 'Desistance and the feared self: toward an identity theory of criminal desistance', Journal of Criminal Law and Criminology 2009, 4, p. 1103-1156.

5 T. Hirschi, Causes of delinquency, Berkely: University of California Press 1969; J.H. Laub \& R.J. Sampson, Shared beginnings, divergent live, Cambridge, MA: Harvard University Press 2003; R.J. Sampson \& J.H. Laub, Crime in the making: Pathways and turning points through life, Londen: Harvard University Press1993.

6 P.C. Giordano, S.A. Cernkovich \& J.L. Rudolph, 'Gender, crime and desistance: Toward a theory of cognitive transformation’, American Journal of Sociology 2002, 4, p. 990-1064; Maruna 2001. 


\section{Toekomstverwachtingen van gedetineerden}

Onderzoek naar verwachtingen van gedetineerden over crimineel gedrag na detentie illustreert dat zij, ondanks de moeilijkheden die hen te wachten staan na vrijlating, over het algemeen een optimistisch beeld van de toekomst hebben. In onderzoek naar de voorspellingen van Amerikaanse en Engelse gedetineerden voor hun leven na detentie bleek dat zij de kans op recidive kleiner schatten dan op basis van de statistieken verwacht kan worden. ${ }^{7}$ Dit 'onrealistisch optimisme' kan juist zorgen voor meer motivatie en doorzettingsvermogen in situaties waar wellicht weinig kans is op succes, ${ }^{8}$ zoals het terugkeren naar de maatschappij voor langer gestrafte gedetineerden. Maruna concludeerde in zijn onderzoek dat personen die uiteindelijk stopten met criminaliteit, een optimistisch beeld van de toekomst hadden voorafgaand aan hun vrijlating. ${ }^{9}$ Dit in tegenstelling tot degenen die het criminele pad weer op gingen. Maruna's onderzoek was echter retrospectief van aard, waardoor niet kan worden vastgesteld in hoeverre de ex-gedetineerden ook echt een optimistisch denkbeeld hadden ten tijde van vrijlating en niet alleen op het moment dat zij terugkijken op hun leven, wetende dat ze succesvol zijn gestopt. In het verlengde hiervan interviewde Schinkel 21 langgestrafte (ex-)gedetineerden en illustreerde dat het toekomstbeeld net voor vrijlating juist ook onzeker kan zijn en niet heel optimistisch, terwijl deze gedetineerden uiteindelijk wel op het rechte pad blijven. ${ }^{10} \mathrm{Zij}$ wijst het idee af dat een optimistisch denkbeeld nodig is om uiteindelijk te stoppen met criminaliteit en concludeert in plaats daarvan dat denkbeelden optimistischer kunnen worden naarmate iemand eenmaal buiten successen ervaart. Stappen op het pad naar een leven zonder criminaliteit die als succesvol worden ervaren, versterken dan weer optimistisch denken.

\section{Sociale en individuele factoren en stoppen met criminaliteit}

Sociale factoren die vanuit de theorie een rol spelen bij het stoppen met crimineel gedrag zijn bijvoorbeeld het belang van bindingen met ouders, vrienden, werk en/ of school en het vinden van een geschikte partner of waardevol werk. Zulke bindingen kunnen als een zogeheten turning point fungeren, een trigger die verandering in gang zet. ${ }^{11}$ Individuele factoren die vanuit de theorie samen lijken te hangen met succesvol stoppen of doorgaan, leggen de focus op de meer interne, complexe processen die zich binnen een persoon afspelen. Er wordt dan verondersteld dat mensen een actieve rol spelen in het vormgeven van hun leven en er een cognitieve shift binnen een persoon plaats moet vinden voordat de eerste stappen

7 Burnett 1992; M.K. Dhami e.a., 'Prisoners' positive illusions of their post-release success', Law Human Behaviour 2006, 30, p. 631-647; C.A. Visher, N.G. La Vigne \& J.L.Castro, 'Returning home: Preliminary findings of a pilot study of soon-to-be released prisoners in Maryland', Justice Research and Policy 2004, 5, p. 55-74.

8 S.E. Taylor \& J.D. Brown, 'Illusion and well-being. A social psychological perspective on mental health', Psychological Bulletin 1988, 103, p. 193-210.

9 Maruna 2001.

10 M. Schinkel, Being Imprisoned: Punishment, Adaptation and Desistance, Palgrave: Basingstoke Hampshire 2014.

11 Sampson \& Laub 1993. 
naar gedragsverandering worden gezet. ${ }^{12}$ Ondanks het ontbreken van een eenduidige omschrijving is het concept agency een belangrijk begrip in dit proces. De volgende aspecten lijken in ieder geval deel uit te maken van agency: het stellen van doelen en planmatig te werk gaan om deze te bereiken, controle uitoefenen op je eigen keuzes en deze ook weer kunnen aanpassen, en geloof in de kracht van je eigen acties. ${ }^{13}$ Burnett en Maruna definieerden agency uiteindelijk als de motivatie voor (het bereiken van) een doel en het vermogen om dat doel te (kunnen) bereiken, ofwel 'the will and the ways'. ${ }^{14}$

Onderzoek naar sociale en individuele factoren bevestigt de gedragsverandering die vanuit theorie wordt verwacht. Zo verkleint het ontvangen van bezoek in detentie de kans op deviant gedrag in de gevangenis en op recidive wanneer men eenmaal vrij is. ${ }^{15}$ In enkele grote onderzoeken waar specifiek onderzoek werd gedaan naar ex-gedetineerden kwam de rol van werk, familie en partners bij de reintegratie naar voren. ${ }^{16}$ Hieruit blijkt dat familie en partner belangrijke bronnen zijn van emotionele en financiële steun, maar tevens zorgen voor huisvesting en een gevoel van stabiliteit. Eerdergenoemde Burnett en Maruna toonden aan dat gedetineerden die zowel gemotiveerd waren als over zelfvertrouwen beschikten, meer kans hadden om uiteindelijk te stoppen met criminaliteit, en Maruna vond een sterk gevoel van controle over de toekomst en een vertrouwen in eigen kunnen bij personen die gestopt waren met criminaliteit. ${ }^{17}$

Kortom, zowel sociale als meer individuele factoren blijken een grote rol te spelen bij gedragsverandering, zoals stoppen met criminaliteit. In deze studie wordt onderzocht of deze factoren al in een eerder stadium een rol kunnen spelen bij optimistische of pessimistische toekomstverwachtingen met betrekking tot het stoppen met crimineel gedrag.

\section{Combinatie sociale en individuele factoren}

In het huidige onderzoek wordt onderzocht in hoeverre sociale en individuele factoren samenhangen met toekomstverwachtingen. Zoals eerder beschreven, wordt verondersteld dat de factoren uit de hiervoor genoemde theorieën een rol zullen spelen bij de verwachting om te stoppen met criminaliteit, en wanneer deze invalshoeken worden gecombineerd, kunnen personen in vier categorieën vallen (zie tabel 1). Op basis van de theorieën en eerder onderzoek wordt verwacht dat personen die hoog scoren op beide factoren (veel en/of hechte bindingen en een

12 Giordano, Cernkovich \& Rudolph 2002; Maruna 2001.

13 A. Bandura, 'Towards a psychology of human agency', Perspectives on Psychological Science 2006, 1, p. 164-180; Paternoster \& Bushway 2009.

14 R. Burnett \& S. Maruna, 'So "prison works", does it? The criminal careers of 130 men released from prison under Home Secretary', Howard Journal of Criminal Justice 2004, 43, p. 390-404.

15 J.C. Cochran, 'Breaches in the wall: imprisonment, social support, and recidivism', Journal of Research in Crime and Delinquency 2014, 2, p. 200-229; G. Duwe \& V. Clark, 'Blessed be the social tie that binds: The effects of prison visitation on offender recidivism', Criminal Justice Policy Review 2013, 3, p. 271-296.

16 A. Ramakers e.a., 'Werk(kenmerken) en recidiverisico's na detentie in Nederland', Tijdschrift voor Criminologie 2014, 2, p. 67-89; R.L. Naser \& N.G. LaVigne, 'Family support in the prisoner reentry process: expectations and realities', Journal of Offender Rehabilitation 2006, 1, p. 93-106.

Burnett \& Maruna 2004; Maruna 2001. 
Tabel 1. Typologie sociale en individuele factoren en hypotheses

\begin{tabular}{llll}
\hline Type & $\begin{array}{l}\text { Sociale facto- } \\
\text { ren }\end{array}$ & Individuele factoren & $\begin{array}{l}\text { Verwachte richting toekomstver- } \\
\text { wachting op basis van literatuur en } \\
\text { eerder onderzoek }\end{array}$ \\
\hline I & + & + & Niet-crimineel \\
II & - & - & Crimineel \\
III & + & - & Tussen niet-crimineel en crimineel in \\
IV & - & + & Tussen niet-crimineel en crimineel in \\
\hline
\end{tabular}

Noot: een plusteken betekent een hoge score, een minteken een lage score.

hoge mate van agency) sterke verwachtingen zullen hebben om te stoppen met criminaliteit, en dat personen die op beide factoren laag scoren (weinig en/of zwakke bindingen en lage mate van agency) geen of minder de verwachting zullen hebben om te stoppen met criminaliteit. Voor personen die zowel een hoge als een lage score hebben op de factoren is het moeilijker om richting te geven aan hun toekomstverwachtingen met betrekking tot crimineel gedrag, maar hoogstwaarschijnlijk vallen zij tussen een hele sterke verwachting en geen verwachting om te stoppen in.

\section{Methode}

\section{Procedure en deelnemers}

Het huidige onderzoek vond plaats in het kader van het Prison Project, een longitudinaal onderzoek naar de effecten van detentie waarbij mannelijke gedetineerden worden gevolgd die in Nederland zijn geboren en tussen de 18-65 jaar zijn. ${ }^{18}$ De huidige onderzoeksgroep voldoet aan dezelfde basiscriteria als de deelnemers van het Prison Project, maar richt zich op langer gestrafte gedetineerden die (a) tweeënhalf tot vier jaar in detentie hebben vastgezeten op het moment dat zij uitstromen, (b) veroordeeld zijn voor een delict waarbij het vonnis niet meer in hoger beroep loopt, en (c) niet veroordeeld zijn voor een zedendelict. Aangezien slechts vier respondenten van de originele Prison Project-groep konden worden meegenomen, is een aanvullende dataverzameling opgezet op basis van een nieuwe lijst, verstrekt door de Dienst Justitiële Inrichtingen (DJI), met potentiële respondenten van wie de geplande datum van vrijlating ${ }^{19}$ lag in de periode september 2014 tot en met oktober 2015. Het was voor het huidige onderzoek belangrijk dat de respondenten vlak voor vrijlating werden benaderd. Hoewel de lijst bestond uit 363 potentiële deelnemers, konden 279 van hen snel geëxcludeerd worden. De overgrote meerderheid verbleef niet meer in een gesloten

18 A. Dirkzwager \& P. Nieuwbeerta, Prison Project: Codeboek en documentatie, Leiden/Amsterdam: Universiteit Leiden/NSCR 2014.

19 Vrijlating betekent hier overigens dat ze in het kader van een voorwaardelijke invrijheidsstelling na twee derde van hun straf met een elektronische enkelband naar huis gingen of doorstroomden naar een open inrichting, waarbij veel vrijheid werd verkregen. 
inrichting (maar in een open inrichting, in een instelling voor begeleid wonen of in een kliniek) ${ }^{20}$ of bleek bijvoorbeeld toch voor een zedendelict veroordeeld te zijn of in een ISD $^{21}$ te verblijven. Slechts 84 (exclusief de vier Prison Projectrespondenten) langer gestrafte gedetineerden in dertien penitentiaire inrichtingen waren geschikt om te benaderen voor deelname, en aan het eind van de dataverzameling in oktober 2015 zijn 40 mannen van deze lijst (op volgorde van geplande datum vrijlating) benaderd. Hiervan zijn 32 mannen geïnterviewd, maar acht interviews moesten uitgesloten worden om diverse redenen. ${ }^{22}$ Uiteindelijk zijn (samen met de vier Prison Project-respondenten) interviews met 28 mannen in de laatste fase van hun detentie gebruikt voor het huidige artikel.

De deelnemende respondenten zijn persoonlijk door de hoofdonderzoeker benaderd. Daarbij is uitleg gegeven over het onderzoek, is vrijwillige deelname benadrukt en zijn de respondenten geïnformeerd over de vertrouwelijkheid van de gegevens en waarborging van de privacy. De interviews zijn afgenomen in een afzonderlijke ruimte waarbij geen derden aanwezig waren of konden meeluisteren. Met toestemming van de respondenten zijn 26 van de 28 interviews opgenomen. Als de respondent geen toestemming gaf (of als de voicerecorder tijdelijk uit moest van de respondent), zijn notities gemaakt en meteen na het interview uitgeschreven. De interviews duurden één tot twee uur en zijn afgenomen op meerdere locaties van acht verschillende penitentiaire inrichtingen.

De gemiddelde leeftijd van de respondenten ten tijde van het interview was 27 jaar, waarbij de jongste 20 en de oudste 53 jaar was. In tabel 2 staan enkele kenmerken van de geïnterviewde respondenten. Het merendeel zit voor een gewapende overval vast (diefstal met geweld). In verband met de vertrouwelijkheid heeft elke respondent een andere naam gekregen.

\section{Interviews, codering en analyse}

Er zijn semigestructureerde diepte-interviews afgenomen, waarbij een interviewprotocol is opgesteld op basis van onderwerpen die uit de theorieën en eerder onderzoek naar voren kwamen als factoren die mogelijk van invloed zijn op het proces van stoppen met criminaliteit en de hiermee gepaard gaande toekomstverwachtingen.

In het interview zijn respondenten bevraagd over hun verwachtingen met betrekking tot crimineel gedrag in de toekomst en het beeld van de respondenten over hun leven na detentie. Waar kijken ze naar uit en waar maken ze zich het meest zorgen om voor straks? De sociale factoren komen in het interview terug in de vorm van vragen over de woon- en werksituatie en de (ontwikkeling van de) relatie met partner, ouders, kinderen en vrienden. Daarnaast zijn vragen toegevoegd

20 Het is mogelijk dat personen die niet meer in een gesloten gevangenis verbleven, verschillen van degenen die wel benaderd konden worden, bijvoorbeeld dat ze relatief goed gedrag vertoonden waardoor ze verder in hun detentiefaseringstraject zaten.

21 Personen die verbleven in een Inrichting voor Stelselmatige Daders (ISD) zijn niet meegenomen.

22 Bijvoorbeeld omdat tijdens of na het interview bleek dat deze gedetineerden toch een langere straf of kortere straf bleken te hebben of al een aaneensluitende straf in het buitenland uitgezeten te hebben. 
Tabel 2. Kenmerken van de respondenten

\begin{tabular}{|c|c|c|c|c|}
\hline Resp & Naam & Leeftijd & Straf & Delict \\
\hline 1 & Peter & $50-54$ & 2-3 jaar & Verduistering \\
\hline 2 & Dave & $20-24$ & 2-3 jaar & Diefstal met geweld \\
\hline 3 & Tom & $30-34$ & 2-3 jaar & Diefstal met geweld \\
\hline 4 & Charles & $20-24$ & 2-3 jaar & Diefstal met geweld \\
\hline 5 & Simon & $20-24$ & 4-5 jaar & Diefstal met geweld \\
\hline 6 & Rudy & $25-29$ & 4-5 jaar & Diefstal met geweld \\
\hline 7 & Bart & $30-34$ & 4-5 jaar & Diefstal met geweld \\
\hline 8 & Tony & $20-24$ & 2-3 jaar & Diefstal met geweld \\
\hline 9 & Roy & $25-29$ & 4-5 jaar & Diefstal met geweld \\
\hline 10 & Wessel & $20-24$ & 4-5 jaar & Poging tot doodslag \\
\hline II & $\mathrm{Ab}$ & $20-24$ & 2-3 jaar & Diefstal met geweld \\
\hline 12 & Jack & $25-29$ & 4-5 jaar & Diefstal met geweld \\
\hline 13 & Leon & $20-24$ & 2-3 jaar & Diefstal met geweld \\
\hline 14 & Aaron & $30-34$ & 2-3 jaar & Diefstal met geweld \\
\hline 15 & Kay & $25-29$ & 4-5 jaar & Diefstal met geweld \\
\hline 16 & Martin & $20-24$ & 4-5 jaar & Diefstal met geweld \\
\hline 17 & Pascal & $30-34$ & 4-5 jaar & Diefstal met geweld \\
\hline 18 & Vince & $25-29$ & 4-5 jaar & Diefstal met verzwarende omstandigheden \\
\hline 19 & Xavier & $20-24$ & 4-5 jaar & Diefstal met geweld \\
\hline 20 & Casper & $35-39$ & 2-3 jaar & Vrijheidsberoving, afpersing \\
\hline 21 & Nick & $20-24$ & 4-5 jaar & Diefstal met geweld \\
\hline 22 & Chris & $25-29$ & 4-5 jaar & Diefstal met geweld \\
\hline 23 & Isaac & $30-34$ & 4-5 jaar & Diefstal met geweld \\
\hline 24 & Nathan & $20-24$ & 4-5 jaar & Diefstal met geweld \\
\hline 25 & Richard & $20-24$ & 2-3 jaar & Diefstal met geweld \\
\hline 26 & Milo & $25-29$ & 4-5 jaar & Poging tot doodslag \\
\hline 27 & Oscar & $20-24$ & 4-5 jaar & Diefstal met geweld \\
\hline 28 & Sam & $20-24$ & 4-5 jaar & Diefstal met geweld \\
\hline
\end{tabular}

waarmee dieper kon worden ingegaan op individuele factoren omtrent agency. Hierbij moet bijvoorbeeld gedacht worden aan vragen over geloof in eigen kunnen, gevoel van controle en persoonlijke doelen. Een vraag als: 'Kun je je eigen lot beïnvloeden of overkomt het leven je?' zorgt voor een gesprek over het maken van keuzes, geluk en in hoeverre iemand denkt invloed te hebben op de gebeurtenissen in het leven.

De interviews zijn getranscribeerd en vervolgens gecodeerd en geanalyseerd met behulp van Atlas-ti. Op basis van het interviewprotocol en de literatuur is deels 
vooraf een codeboom opgesteld (a priori coderen ${ }^{23}$ ); dit is gaandeweg aangevuld met codes die vanuit het materiaal zijn ontstaan. Op basis van de uit de interviews verkregen informatie zijn de respondenten ingedeeld in de vier eerder beschreven profielen. De beschikbare informatie uit de semigestructureerde interviews is breed en betreft vele onderwerpen. Om de informatie goed te benutten en te interpreteren zijn de uitgeschreven interviews herhaaldelijk doorgenomen, waarbij niet alleen naar de feitelijk door de respondenten uitgesproken zinnen is gekeken, maar ook naar de meer algemene inhoudelijke strekking. Uiteraard bevat de interpretatie van de interviews een mate van subjectiviteit. Om de subjectiviteit enigszins uit te sluiten zijn de uitgeschreven interviews onafhankelijk door twee onderzoekers gelezen en zijn de respondenten op basis van de sociale en individuele factoren ingedeeld in de vier profielen (zie tabel 1). De door de twee onderzoekers gemaakte indelingen kwamen zeer overeen. In de drie gevallen dat er een verschil van interpretatie bestond tussen de onderzoekers, is op basis van een uitgebreide screening van het materiaal en discussie tot consensus gekomen.

Een hoge score op de sociale factoren betekent dat een persoon twee of meer sterke bindingen heeft. Om dit te bepalen is gekeken naar de woonsituatie en het niet-criminele vriendennetwerk van de persoon, maar ook in hoeverre de persoon een baan of andere dagbesteding heeft, een partner en/of kinderen heeft, en een relatie met zijn ouders onderhoudt. ${ }^{24}$ Niet alle bindingen waren noodzakelijk om een hoge score te krijgen, en niet alleen de aan- of afwezigheid van een binding, maar ook de inhoud en sterkte van deze binding hebben bijgedragen aan de indeling in een hoge of lagere score. Hierbij is het goed om te vermelden dat bij de sociale factoren is gekeken naar de huidige situatie. Met andere woorden: heeft iemand (op het moment van het interview) onderdak en dagbesteding na vrijlating? Aangezien de interviews gemiddeld drie maanden voor vrijlating plaats hebben gevonden, zou het mogelijk kunnen zijn dat de gedetineerden op het moment van het interview nog geen zicht hadden op eerdergenoemde sociale factoren, maar wellicht twee maanden later wel. Een hoge score op de individuele factoren betekent dat in de antwoorden van een persoon een hoge mate van agency naar voren kwam. Om dit te bepalen is gekeken in hoeverre de persoon aangeeft een gevoel van controle over zijn leven en de toekomst te ervaren, de eigen verantwoordelijkheid voor het leven benadrukt, persoonlijke doelen die hij nastreeft formuleert, en een geloof in eigen kunnen lijkt te hebben. Wanneer twee of meer van deze elementen duidelijk naar voren kwamen in het interview, heeft een persoon een hoge score voor individuele factoren gekregen. In de resultatenparagraaf (zie hierna) worden de sociale en individuele factoren van de respondenten uitgebreid

23 M.B. Miles \& A.M. Huberman, Qualitative data analysis: an expended sourcebook, Londen: Sage 1994.

24 Werk en inkomen, onderdak, hulp bij schulden en een goed sociaal netwerk zijn basisvoorwaarden voor een goede terugkeer in de samenleving. Hier wordt zo veel mogelijk in detentie al aan gewerkt; Ministerie van Veiligheid en Justitie \& Vereniging van Nederlandse Gemeenten, Convenant 'Richting aan Re-integratie', Re-integratie van (ex-)gedetineerden, Den Haag: Ministerie van VenJ/VNG 2014. 
besproken en worden tevens enkele citaten gegeven die een hoge of lage score op deze factoren illustreren.

\section{Resultaten}

\section{Toekomstverwachtingen}

Op basis van de antwoorden op de vragen over hun toekomstverwachtingen, kwam een indeling naar voren van gedetineerden die zeker verwachten te gaan stoppen met criminaliteit (niet-criminele verwachting, $\mathrm{n}=11$ ), gedetineerden die zeker verwachten dat ze doorgaan met criminaliteit (criminele verwachting, $\mathrm{n}=10$ ) en gedetineerden die daar onzeker over zijn (onzekere verwachting, $\mathrm{n}=7$ ). De verwachting om geen crimineel gedrag meer te vertonen na vrijlating wordt geillustreerd door Dave:

'Nee hoor, ik ga echt geen dingen meer doen buiten, ik heb al genoeg jaren weggegooid!'

Tien van de 28 gedetineerden verwachten dat ze na hun detentie gewoon door zullen gaan met criminaliteit, al geven de meesten aan dat dit met minder ernstige criminele activiteiten zal zijn dan waarvoor ze nu zijn veroordeeld (bijvoorbeeld drugs dealen in plaats van overvallen plegen). Tot slot zijn zeven gedetineerden onzeker en onduidelijker over hun toekomstige gedrag. Zij betwijfelen of ze gaan stoppen met criminaliteit. Sommigen zeggen dit wel te willen, maar geven tegelijkertijd aan dat ze niet zeker zijn of ze ook daadwerkelijk zouden stoppen. Zoals Vince beschrijft:

'De kans dat ik hier terugkom? Zucht... durf ik niet te zeggen. Ik denk 50 50, laten we het daarop houden. Ja, kijk ik had ook slechte gewoontes, ik ging gokken, deed drugs, feesten.'

\section{Sociale en individuele factoren en toekomstverwachtingen}

Om inzicht te krijgen in de vraag in hoeverre sociale en individuele factoren samenhangen met toekomstverwachtingen zijn de respondenten op basis van hun antwoorden ingedeeld in de vier eerder beschreven typologieën. Tabel 3 laat de uitkomsten hiervan zien in combinatie met de toekomstverwachtingen.

\section{Type I: hoog sociale factoren, hoog individuele factoren $(n=5)$}

De vijf respondenten in deze groep hebben meerdere sterke bindingen in de vorm van woning, werk, partner, kind en een goede band met de ouders of moeder. Ze voelen zich gesteund door hun sociale contacten en hebben hier in detentie ook regelmatig contact mee. Tevens lijkt de steun van de ouders terug te komen in de verwachting dat ze na detentie weer thuis worden verwelkomd. Vier van de vijf respondenten in deze groep hebben één of meer kinderen en drie van hen onderhouden een hechte band met de kinderen. De respondenten zien hun kinderen bij 
Tabel 3. Typologie sociale en individuele factoren in combinatie met toekomstverwachtingen

\begin{tabular}{lllll}
\hline Type & $\begin{array}{l}\text { Sociale } \\
\text { factoren }\end{array}$ & $\begin{array}{l}\text { Individuele } \\
\text { factoren }\end{array}$ & $\mathbf{n}=$ & Toekomstverwachting \\
\hline I & + & + & 5 & $\begin{array}{l}\text { Niet-crimineel (4) Onzeker (I) } \\
\text { II }\end{array}$ \\
III & + & - & 12 & $\begin{array}{l}\text { Niet-crimineel (2) Crimineel (9) } \\
\text { Onzeker (I) }\end{array}$ \\
IV & - & - & 5 & $\begin{array}{l}\text { Niet-crimineel (I) Onzeker (4) } \\
\text { Niet-crimineel (4) Crimineel (I) } \\
\text { Onzeker (I) }\end{array}$ \\
\hline
\end{tabular}

Noot: een plusteken betekent een hoge score, een minteken een lage score.

bezoek of verlof en praten in termen van missen, rolmodel, een goede vader willen zijn en de behoefte om hun kind te zien opgroeien. In deze groep wordt weinig gesproken over vrienden.

Met betrekking tot de individuele factoren lijkt de focus bij deze respondenten te liggen op het heft in eigen hand nemen. Oude 'vrienden' en het leven op straat hebben hen namelijk niet veel goeds gebracht, volgens hen, maar ze nemen daar wel hun verantwoordelijkheid voor. Een inzicht dat respondenten zelf ter sprake brengen:

'Nu door detentie, dit heeft me laten stilstaan bij wat ik tot nu toe in mijn leven heb bereikt: geen klote! En ik heb altijd maar lopen rotzooien, rondhangen op straat, nooit mijn school afgemaakt, steeds weer van opleiding veranderen. En dan had ik eindelijk een opleiding waar ik iets mee kon en kijk wat ik met m'n stomme kop doe, ik gooi gewoon mijn eigen glazen kapot. Op een gegeven moment dacht ik, dit moet veranderen.' (Dave)

Alle respondenten in deze groep geven aan een gevoel van controle over de eigen toekomst en over het bereiken van gestelde doelen te ervaren. Tevens lijkt dat hun een gevoel van optimisme te geven dat ze de toekomst aankunnen. Respondenten voelen zich redelijk zelfverzekerd over hun eigen vaardigheden en lijken zich te willen distantiëren van het criminele leven.

De type I-gedetineerden verwachten bijna allemaal dat ze zich niet meer met criminele activiteiten inlaten. De steun die uit de sociale bindingen voortvloeit in de vorm van huisvesting na detentie en een kind of partner die veel voor hen betekent, speelt een grote rol bij deze positieve toekomstverwachting. Het volgende fragment illustreert het belang van de inhoud en de sterkte van een binding. Deze respondent heeft al eens een vriendin gehad, maar toen is hij niet gestopt met criminele activiteiten. $\mathrm{Nu}$ is dat anders:

'R: Doordat zij ook op mijn pad kwam heeft ze me geholpen, want zij trok me meer weg van daar. En hielp me met m'n dingen en ik zag vooruitgang. Want toen ik met haar in het begin ging, ging ik veel dingen niet meer doen. Toen zag ik van, ik had die stress niet, ik was relaxed, en ik genoot elke dag! Dus 
toen dacht ik van laat me voor die kiezen. En ik heb het nooit, nooit een kans gegeven. Voor de rest hoe ik terecht komt buiten, nou dat komt allemaal goed dat weet ik wel.

I: Hoezo weet je dat zo zeker?

R: Ja nou gewoon, want ik weet wie ik achter me heb en om me heen. En ik weet wat ik wil. ik ken het al, criminaliteit en kinderen hebben en samenwonen. Maar ik ken nog niet: werken en zonder stress en zonder problemen.. Ik heb pad A altijd gedaan, nu maar pad B proberen.' (Tom)

De respondenten hebben een sterke motivatie om niet meer in een situatie terecht te komen waarin ze crimineel gedrag kunnen gaan vertonen, omdat ze zich realiseren hoeveel het hen gekost heeft. Ze lijken vertrouwen te hebben in hun eigen capaciteiten om daadwerkelijk de gestelde doelen te kunnen bereiken. Zo bespreken ze bijvoorbeeld hoe ze actief de verleidingen van het criminele leven en de obstakels gaan aanpakken:

'Bepaalde dingen zal ik niet meer gaan doen, bepaalde klanten zal ik niet meer aannemen, omdat je moet oppassen dat je daardoor niet in de gevarenzone komt. Daar heb ik geen trek in, want dan kom je snel op een soort hellend vlak. Waarbij geld de norm is geworden. Het is soms ook wijs om te besluiten om iets niet te doen. Dat is ook een besluit.' (Peter)

\section{Type II: laag sociale factoren, laag individuele factoren $(n=12)$}

De twaalf respondenten die in deze categorie vallen, hebben geen, weinig of zwakke sociale bindingen in de vorm van kind(eren), partner en ouders. Ze ontvangen tijdens hun detentie weinig of geen bezoek (meer) van vrienden of familie. Al deze mannen zijn opgegroeid met zaken als geweld en stelen. Van snoepjes stelen en fietsen jatten tot een winkel leeghalen in de puberteit. Bij een leven zonder criminaliteit kunnen ze zich niet zo veel voorstellen.

'Ik vind het niet zo erg dat ik een strafblad heb, ik weet dat mensen mij zien als een crimineel, dat mensen een stempel op mij drukken, maar dat maakt me niet zoveel uit. Ik zit al mijn hele leven in de criminaliteit en ben ook niet van plan om het anders te doen.' (Rudy)

Twee van de twaalf respondenten uit deze groep hebben een partner. Deze partners zijn het volgens de respondenten niet eens met hun levenswijze en maken dat ook geregeld duidelijk, maar ze blijven (nog) wel. In deze groep hebben vier respondenten (stief)kinderen, maar hier lijkt geen sprake van een hechte band. Ze zijn nauwelijks betrokken bij de opvoeding, en van één respondent woont zijn kind zelfs in een ander land. Ze praten niet over 'vrienden', maar het netwerk van de meeste respondenten in deze groep is overwegend crimineel of risicovol.

Met betrekking tot de individuele factoren lijken de gedetineerden in deze groep hun gedrag meer te wijten aan externe factoren. Eén respondent lijkt weinig gevoel van controle over zijn acties te hebben als hij zegt zich niet bewust bezig te houden met criminaliteit, maar dat er soms 'dingen gebeuren die hij niet over zich 
heen kan laten gaan'. Voor de rest van de respondenten in deze groep is het volgens hen geoorloofd (voor nu) om de criminele levensstijl aan te houden, omdat ze bijvoorbeeld geen diploma's hebben en geen werk kunnen vinden. In de interviews leggen ze uit dat ze het proberen te maken, net als ieder ander, maar dat ze obstakels ervaren en het op de legale manier niet voor hen is weggelegd. Overigens zijn ze redelijk zeker van zichzelf wat betreft de criminele acties en het doelgericht handelen om zwart geld te verkrijgen, maar minder zeker van het geloof in eigen kunnen in de conventionele wereld:

'Stoppen? Om eerlijk te zijn... als je dat zakcentje aan de kant niet maakt, een kleine jongen zoals ik die groot probeert te worden in iets wits. We halen het gewoon nooit netjes, ik heb niet alle papieren, ik heb eigenlijk bijna geen papieren, maar ik ben wel creatief. Ik weet hoe ik dingen kan oplossen.' (Tony)

Van de twaalf type II-gedetineerden zien negen een niet-criminele toekomst (nog) niet voor zich. In hun beleving zijn ze mede door hun verleden of de omgeving de criminele kant op gedreven en vinden ze het moeilijk om hier actief een andere draai aan te geven. Het gebrek aan prosociale bindingen (partner, kinderen, ouders) maakt dit proces niet makkelijker. De (criminele) vrienden lijken een belangrijke rol te spelen bij de negatieve toekomstverwachting, aangezien ze aangeven veelal terug te (willen) keren naar dit netwerk in combinatie met, zoals Tony hiervoor beschrijft, een onzeker geloof in eigen kunnen in de conventionele wereld. Binnen deze groep zijn twee respondenten die een niet-criminele toekomst voor zich zien en hier erg zeker over zijn.

\section{Type III: hoog sociale factoren, laag individuele factoren $(n=5)$}

In deze groep zitten vijf personen die meerdere bindingen hebben op het gebied van woning, werk, ouders, kinderen en/of niet-criminele vrienden. Op één na zijn ze allemaal onder de 30 jaar en, ondanks het soms criminele verleden, lijkt het sociale vangnet van deze jongemannen sterk. Ze kunnen na detentie terecht bij hun ouders, met wie ze een goede band zeggen te hebben, en twee van de zes denken te kunnen terugkeren naar hun oude werkgever. Vince heeft daarnaast een dochter voor wie hij graag een vader wil zijn en een niet-criminele vriendengroep waarvoor hij veel waardering uitspreekt:

'Dat zijn echt vrienden van de tijd voordat ik crimineel werd. Toen ik het andere pad heb gekozen, zijn zij gewoon normaal gebleven. Zij zullen er ook voor me zijn als ik straks vrij kom. Ze vragen me wel altijd wat ik aan het doen ben, maar ja... ik kies vaak voor de makkelijkste weg.' (Vince)

Maar ze scoren niet op alle sociale vlakken hoog. Geen van deze respondenten heeft namelijk een partner - wat kan samenhangen met de jonge leeftijd - en sommigen zijn erg onzeker over een plan om straks geld te gaan verdienen.

Op de individuele factoren scoren deze respondenten ongunstig. Ze lijken niet goed te weten wat hun doelen zijn - dit kan wederom samenhangen met de jonge 
leeftijd - en wat ze daarvoor moeten doen om die te bereiken. Daarnaast is het geloof in eigen kunnen en de controle die hierop kan worden uitgeoefend om zelf op het rechte pad te blijven twijfelachtig. Zoals een van hen illustreert:

'Nee, nee. Ik wil niet hier terug gaan komen, maar een ongeluk zit in een klein hoekje. Maar wat ik wel kan zeggen, voor dit delict kom ik niet meer vast te zitten. Maar ja, er kan altijd nog wat gebeuren, je weet maar nooit weet je?' (Xavier)

Eén respondent blijkt overigens wel doelgericht te handelen in zijn criminele acties. Net als bij de type II-respondenten heeft hij veel vertrouwen in zijn eigen vermogen om criminele activiteiten succesvol te volbrengen, maar voor het conventionele leven is hij hier niet zeker van.

Bijna alle type III-respondenten zien een onzekere toekomst voor zich met betrekking tot hun criminele activiteiten. Het is niet dat ze helemaal niet denken aan stoppen met criminaliteit, maar in de interviews zijn ze er zelf niet erg van overtuigd. Volgens hen heeft dat te maken met het niet weten wat de toekomst brengt. Hun matige geloof in zichzelf en de mogelijkheden om invloed uit te kunnen oefenen op hun leven lijkt mee te spelen bij die onzekerheid over wat de toekomst brengt en dus bij hun onzekerheid of ze daarmee om kunnen gaan.

\section{Type IV: laag sociale factoren, hoog individuele factoren $(n=6)$}

De respondenten in deze groep hebben weinig, geen of zwakke bindingen in de vorm van werk en woning. Niemand heeft een partner bij wie ze terug kunnen keren, en in hun omgeving zijn veel criminele vrienden van wie ze nu afstand proberen te nemen. Een van de respondenten in deze groep heeft kinderen over wie hij vol lof praat, maar tevens enigszins schaamtevol, omdat hij zo vaak afwezig was in de opvoeding. Overigens vertellen de type IV-respondenten dat ze wel een goede band hebben met hun ouders, maar uit het interview blijkt dat ze dezen maar weinig zien, dat ze al oud zijn en/of zelf in de criminaliteit zitten.

Op de individuele factoren scoren deze respondenten redelijk hoog. Voor sommige respondenten voelt het als een soort nieuwe missie om te kijken of ze op een andere manier kunnen leven. Misschien ook een nieuwsgierigheid naar hoe 'normale' mensen leven en het conformeren aan de conventies. In de verhalen is duidelijk het element van controle op je eigen leven uitoefenen terug te lezen. Respondenten tonen een voornemen of vastberadenheid om zelf richting te geven aan hun leven:

'R: Ik ben nu al monteur, ik kan schilderen, ik heb mijn VCA, ${ }^{25}$ dus ik hoop dat ik daarmee aan de slag kan. Ik ga naar dat Exodus huis, niets gaat me van dat pad houden, ik wil daarheen.

I: Wat is het belangrijkste voor jou om te stoppen met criminaliteit?

25 VCA staat voor Veiligheid Checklist Aannemers en is een certificaat dat veel wordt gevraagd in technische branches zoals de bouw of elektrotechniek. Deze cursus kunnen gedetineerden tijdens hun detentie volgen. 
R: Ik wil niet door deze mensen worden geleefd. Ik wil m'n eigen beslissingen kunnen nemen, goede beslissingen.' (Isaac)

De zes respondenten van dit type zijn allen ervaren in de criminele wereld en de meesten hebben nu een soort inzicht of besef dat het leven dat ze hebben geleid niet (meer) voldoet aan wat ze nu willen. De vragen over lot en zelf beslissingen nemen illustreren waar de criminele wereld in hun beleving voor staat en dat daar zelf verantwoordelijkheid voor moet worden genomen:

'R: Wij van de straat zijn helemaal niet zo cool. Er zijn risico's aan verbonden en die risico's maken dat je het niet volhoud. Of je dood gaat dat ligt helemaal aan jezelf. Jij bepaalt hoe je zaken doet. De keuze heeft altijd bij jou gelegen, je kunt je distantiëren, ook op straat, je kan zeggen "nee het is niets voor mij".

I: In hoeverre denk je dat het leven je overkomt of dat je je eigen lot bepaalt? $\mathrm{R}$ : Je lot is je situatie waar je in verkeert of gaat verkeren en dan moet je altijd proberen zoveel mogelijk invloed op uit te oefenen. En dat kan zowel actief als passief. Maar je moet nooit verwachten dat alles maar uitgestippeld is. Picasso was een groot schilder, maar zijn zoon was een mislukkeling, omdat succes niet bepaald wordt door de situatie of de omstandigheden die je krijgt bij je geboorte maar door de invloed die jij uitoefent op die omstandigheden of situaties. Dus, ja, je moet altijd gebruik maken van de invloed die je uit kan oefenen. Dat met een stukje optimisme denk ik.' (Richard)

De toekomstverwachtingen bij de type IV-respondenten zijn overwegend nietcrimineel. Een ander pad volgen en hierin geloven lijkt juist ook door het gebrek aan sociale bindingen (en dus een streven hiernaar) bij te dragen aan een nietcriminele verwachting. Zo zegt Sam:

'Als nu iemand naar mij toe komt, we kunnen dit gaan doen, of dat... Denk er over na. Dan laat ik die dingen gewoon zitten. Ga ik gewoon mijn eigen pad op. Misschien is het nu makkelijk praten omdat ik vast zit, maar... Ik denk nu niet meer zo. Je wordt ook ouder... Ik wil echt mijn kinderen gewoon... Dus ik wil nu echt gaan werken, huisje...' (Sam)

Aan de andere kant is er tevens een onzekere en criminele toekomstverwachting binnen deze groep, waarbij het gebrek aan prosociale perspectieven wel een aandeel lijkt te hebben. Zo heeft Milo een inzicht dat hij eigenlijk niet meer door wil leven op de manier zoals hij dat altijd gedaan heeft, maar geeft hij wel aan zijn criminele activiteiten gewoon weer op te pikken:

'Nee, ik ben niet blij dat het zo is. Maar, ja, aan de ene kant ben je wel blij dat je toch nog op iets kunt terugvallen. Maar aan de andere kant is het geen leven meer. Het is niet het juiste leven. Je moet wat. Of ik kan twee maanden wachten op salaris of uitkering, dan zijn we nog geen steek verder. Ik kan naar school gaan, dan moet ik het nog zelf betalen. Ik kan productiewerk gaan 
doen of in de techniek, maar ja. Dat wil ik niet tot mijn 60e willen doen. Alsjeblieft niet.' (Milo)

\section{Discussie}

Het huidige onderzoek richt zich op langer gestrafte gedetineerden in Nederland die na een detentieduur van een aantal jaren weer terugkeren naar de maatschappij. Tot op heden is er weinig bekend over deze specifieke groep gedetineerden, terwijl ze verantwoordelijk zijn voor de meer ernstige criminaliteit. Het doel van het artikel is enerzijds om te onderzoeken wat hun toekomstverwachtingen zijn aan het eind van hun straf, en anderzijds om te onderzoeken in hoeverre sociale factoren - zoals werk, woning, steun van partner of familie - en individuele factoren - zoals geloof in eigen kunnen en een gevoel van controle - samenhangen met die toekomstverwachtingen ten aanzien van crimineel gedrag. Meer inzicht in de toekomstverwachtingen ten aanzien van criminele activiteiten is van belang omdat zulke verwachtingen van invloed kunnen zijn op daadwerkelijk (crimineel) gedrag en de gedetineerde mogelijk al eerder ondersteund zou kunnen worden in het re-integratieproces.

Uit de interviews blijkt dat de onderzoeksgroep vlak voor vrijlating een nietcriminele verwachting, een criminele verwachting of een onzekere verwachting had voor de toekomst. Op basis van theorieën en eerder onderzoek die sociale en individuele factoren benadrukken, ${ }^{26}$ zijn vervolgens vier groepen langgestraften beschreven, gebaseerd op een hoge of lage score op sociale factoren én een hoge of lage score op individuele factoren. Gedetineerden die hoog scoren op sociale factoren hebben bijvoorbeeld meerdere sterke bindingen, onder andere doordat ze een baan of een partner hebben en zich gesteund voelen door familie. Gedetineerden die hoog scoren op individuele kenmerken ervaren een gevoel van controle over hun toekomst en hebben een geloof in eigen kunnen om bijvoorbeeld te stoppen met crimineel gedrag. Op basis van de theorieën en eerder onderzoek die sociale en individuele factoren bij het proces van stoppen met criminaliteit benadrukken, zijn verwachtingen opgesteld over de relatie tussen de sociale en individuele factoren enerzijds en de wijze waarop gedetineerden naar de toekomst kijken anderzijds. In overeenstemming met die verwachtingen lijken het beschikken over een huis of baan, de steun van ouders, partner en/of kind in combinatie met een sterk geloof in eigen kunnen en gevoel van controle samen te hangen met een toekomstverwachting om te gaan stoppen met crimineel gedrag. Het gebrek hieraan hangt andersom ook samen met de verwachting door te gaan met criminaliteit. Kortom, de resultaten laten zien dat een positiever toekomstbeeld om op het rechte pad te blijven vaker voorkomt bij langgestrafte gedetineerden die zich aan het eind van hun straf capabel genoeg vinden en het gevoel hebben het heft in eigen handen te kunnen nemen. Dit komt overeen met het gedachtegoed van onder anderen Giordano en Maruna, waarbij verondersteld wordt dat dit beeld voor de toekomst een grote rol speelt bij het daadwerkelijk stoppen met criminali- 
teit. Sociale bindingen lijken voor meer zekerheid en zelfvertrouwen hierin te zorgen, maar het gebrek aan bindingen levert bij personen die wel een hoge mate van agency hebben tevens een niet-crimineel toekomstbeeld op. De afwezigheid of zwakte van deze bindingen lijkt in die gevallen juist voor meer stimulans te zorgen om een niet-criminele toekomst na te streven, zodat het beeld van 'huisje, boompje, beestje' alsnog in het verschiet ligt. Een overwegend onzekere verwachting met betrekking tot crimineel gedrag is wel terug te zien bij personen die een matig geloof hebben in eigen kunnen, maar wel blijken te beschikken over meerdere en/of sterke prosociale bindingen. Een hoge score op de individuele factoren levert dus een overwegend niet-criminele toekomstverwachting op, maar een hoge score op alleen sociale factoren lijkt niet genoeg te zijn voor een toekomstbeeld zonder criminaliteit. Waar familie en partners uit eerder onderzoek een belangrijke bron zijn van steun, en zorgen voor een gevoel van stabiliteit in het re-integratieproces, ${ }^{27}$ blijkt uit huidig onderzoek dat deze factoren inderdaad gereflecteerd worden in de niet-criminele toekomstverwachting van personen die hier inderdaad op kunnen rekenen, maar dat een gebrek hieraan niet meteen zorgt voor een pessimistische verwachting voor na detentie.

Het huidige onderzoek kent enkele beperkingen. Allereerst is een relatief kleine - en mogelijke selectieve - groep mannelijke gedetineerden geïnterviewd. Niettemin vond het huidige onderzoek plaats in diverse penitentiaire inrichtingen verspreid over het hele land en zijn respondenten geselecteerd op basis van een landelijke lijst met alle gedetineerden die aan de inclusiecriteria voldeden. Ten tweede richtte het huidige onderzoek zich op langgestrafte mannelijke gedetineerden in Nederlandse gevangenissen. Toekomstig onderzoek waarbij ook andere langgestrafte gedetineerden (bijvoorbeeld vrouwen) of langgestrafte gedetineerden in andere landen worden onderzocht, is nodig om te bepalen in hoeverre de in dit onderzoek gevonden resultaten ook in een andere context gelden.

Ondanks voornoemde beperkingen levert het huidige onderzoek nieuwe kennis op met betrekking tot langgestrafte gedetineerden en hun toekomstverwachtingen. Dit is van belang, omdat als verwachtingen gedrag beïnvloeden, mogelijk eerder ingegrepen kan worden in het proces van re-integratie. Het huidige onderzoek toont aan dat sociale bindingen in interactie met de meer individuele en cognitieve factoren (zoals geloof in eigen kunnen en een gevoel van controle hebben over eigen acties) van belang zijn voor de toekomstverwachting te gaan stoppen met criminaliteit. De individuele factoren hebben daarentegen ook los van de sociale factoren een aandeel in niet-criminele toekomstverwachtingen. In het Nederlandse detentiesysteem wordt nu al bij iedere gedetineerde in het kader van re-integratie aandacht besteed aan diverse leefgebieden, zoals werk en woning, en kunnen gedetineerden bij goed gedrag in aanmerking komen voor gedragsinterventies om cognitieve vaardigheden te vergroten. ${ }^{28}$ Maar de onderzoeksresultaten impliceren ook dat het waardevol is dit systeem uit te breiden door meer aandacht te besteden aan individuele factoren zoals zelfvertrouwen en zelf-effectivi-

28 L. van Gent, Handleiding Toetsingskader promoveren en degraderen, Den Haag: Dienst Justitiële Inrichtingen 2013. 
teit van gedetineerden, zodat ze het gevoel hebben zelf richting te kunnen geven aan hun leven als ze vrij komen en zo ook wellicht beter in staat zijn om de uitdagingen die het proces van re-integratie met zich brengt, niet uit de weg te gaan. 